\title{
Relation between severity of liver disease and renal oxygen consumption in patients with cirrhosis
}

A Gadano, R Moreau, J Heller, C Chagneau, F Vachiéry, C Trombino, A Elman, C Denié, D Valla, D Lebrec

\begin{abstract}
Background-Worsening cirrhosis may lead to increased renal $\mathrm{O}_{2}$ metabolism caused by activation of neurohumoral antinatriuretic substances.

Aims-To evaluate the relation between the severity of liver disease, sodium excretion, and neurohumoral antinatriuretic substances on the one hand and renal $O_{2}$ metabolism on the other in patients with cirrhosis.

Methods-Renal $\mathrm{O}_{2}$ consumption and haemodynamics as well as plasma concentrations of noradrenaline, renin, and aldosterone were measured. Investigations were performed in 14 patients with Pugh's grade A, 43 with grade $B$, and 29 with grade $\mathrm{C}$ liver disease.
\end{abstract}

Results-Renal $\mathrm{O}_{2}$ consumption significantly increased with the severity of cirrhosis (grade $A, 8.9$ (1.6); grade $B, 15.5$ (1.3); grade C, $\left.18.0(1.5) \mathrm{ml} / \mathrm{min} / \mathrm{m}^{2}\right)$. Plasma concentrations of noradrenaline, renin, and aldosterone significantly increased while mean arterial presssure and systemic vascular resistance significantly decreased with the severity of the disease. A significant inverse correlation was found between renal $\mathrm{O}_{2}$ consumption and sodium excretion. A significant direct correlation was found between plasma levels of noradrenaline and aldosterone on the one hand and renal $\mathrm{O}_{2}$ consumption on the other. Renal blood flow and the glomerular filtration rate did not differ significantly between patients with grade $C$ and grade $A$ or $B$ disease.

Conclusions-This study shows for the first time that, in patients with cirrhosis, worsening of the disease is associated with an increase in renal $\mathrm{O}_{2}$ consumption. The results suggest that increased renal $\mathrm{O}_{2}$ consumption is due to renal tubular sodium retention caused by increased levels of neurohumoral antinatriuretic substances. This neurohumoral activation is related to cirrhosis induced vasodilation. (Gut 1999;45:117-121)

Keywords: antinatriuretic hormones; cirrhosis; kidney; haemodynamics; $\mathrm{O}_{2}$ consumption; sodium retention

In patients with cirrhosis, neurohumoral antinatriuretic substances (noradrenaline, angiotensin II, and aldosterone) are activated as liver disease deteriorates. ${ }^{1-4}$ In renal tubular cells, neurohumoral antinatriuretic substances stimulate energy and $\mathrm{O}_{2}$ consuming mecha- nisms that increase sodium reabsorption..$^{56}$ Therefore worsening cirrhosis may be associated with an increase in renal $\mathrm{O}_{2}$ consumption. The aim of this study was to evaluate the relation between the severity of cirrhosis and renal $\mathrm{O}_{2}$ consumption. In addition, the relations between sodium excretion and neurohumoral antinatriuretic substances on the one hand and renal $\mathrm{O}_{2}$ consumption on the other were measured.

\section{Patients and methods}

PATIENTS

Studies were performed in 86 patients with histologically proven cirrhosis. The severity of the disease was assessed according to Pugh's classification. ${ }^{7}$ Sixty six patients had ascites and 20 did not. Table 1 shows the main clinical characteristics and laboratory values. Patients with cirrhosis and the following criteria were not included in the study: cardiac failure, respiratory or renal disease (serum creatinine higher than $1.5 \mathrm{mg} / \mathrm{dl}$ ), diabetes mellitus, hepatocellular carcinoma, hepatic encephalopathy, sepsis or spontaneous bacterial peritonitis, gastrointestinal bleeding within the preceding 10 days, treatment with potentially nephrotoxic or non-steroid anti-inflammatory drugs within the preceding month. Patients were placed on a low sodium diet $(30-50$ $\mathrm{mmol} /$ day); daily protein and energy dietary intake were $70-80 \mathrm{~g}$ and $7524 \mathrm{~kJ}(1800 \mathrm{kcal})$ respectively. Sixty seven of the 86 patients were included in prospective controlled studies to investigate the pathophysiological and therapeutical aspects of cirrhosis. Haemodynamic measurements were included in the protocols of these studies. Protocols also indicated the withdrawal of diuretics or vasoactive drugs one week before the haemodynamic investigation. All these studies have been published, and were approved by either the ethics committee of the Faculty of Medicine, University of XavierBichat, Paris ${ }^{89}$ or by the Comité Consultatif de Protection des Personnes dans la Recherche Biomédicale de Paris-Bichat Claude Bernard. $^{10} 11$ Thus 67 patients gave written informed consent to the investigations. The remaining 19 were referred for haemodynamic investigation of portal hypertension. They gave oral consent to the investigations described below because they had received no treatment at the time of the study. Thus we did not have

Abbreviations used in this paper: $\mathrm{Na}^{+} / \mathrm{K}^{+}$ATPase, sodium/potassium dependent adenosine triphosphatase; $\mathrm{PAH}, p$-aminohippurate; $\mathrm{PO}_{2}, \mathrm{O}_{2}$ tension; $\mathrm{So}_{2}$, oxyhaemoglobin saturation; $\mathrm{ANP}$, atrial natriuretic peptide. 
Table 1 Clinical and laboratory characteristics according to the severity of cirrhosis according to Pugh's classification (grade $A, B$, or $C$ )

\begin{tabular}{llll}
\hline & \multicolumn{2}{l}{ Grade } \\
\cline { 2 - 4 } & $A$ & $B$ & $C$ \\
\hline Number of patients & 14 & 43 & 29 \\
Age (years) & $42(2)$ & $49(2)$ & $51(2)$ \\
Sex $(\mathrm{M} / \mathrm{F})$ & $11 / 8$ & $27 / 20$ & $21 / 11$ \\
Number of patients with ascites & $-22(4)$ & 39 & 27 \\
Serum bilirubin $(\mu \mathrm{mol} / \mathrm{l})$ & $64(3)$ & $54(15)$ & $132(25)$ \\
Prothrombin time $(\%)$ & $39.2(1.5)$ & $34.3(0.8)$ & $27.5(1.2)$ \\
Serum albumin $(\mathrm{g} / \mathrm{l})$ & $5.6(0.2)$ & $8.2(0.2)$ & $10.8(0.2)$ \\
Child Pugh score & \multicolumn{2}{l}{}
\end{tabular}

Results are expressed as mean (SEM).

to withdraw any treatment in these patients. Both groups (written and oral consent) met the ethical standards for research as embodied in the Declaration of Helsinki.

On the day of the study, patients were taken to the haemodynamics laboratory. Splanchnic, systemic, and renal haemodynamics, neurohumoral factors and blood gases were measured (see later).

\section{HAEMODYNAMIC MEASUREMENTS}

Patients were placed in a supine position for at least two hours before the study and sedated with meperidine hydrochloride, $50 \mathrm{mg}$ intramuscularly. Catheters were introduced into the right internal jugular vein using a vessel dilator with a polypropylene sheath (Desilets; Vygon, Ecouen, France) under local anaesthesia.

Wedged and free hepatic venous pressures were measured using an $8 \mathrm{~F}$ catheter (Cordis SA, Miami, Florida, USA) introduced into the right hepatic vein. ${ }^{12}$ The hepatic venous pressure gradient was the difference between the wedged and free hepatic venous pressures. The same catheter was used to measure inferior vena cava pressure in relation to the right renal vein.

Systemic haemodynamics were studied using a Swan-Ganz pulmonary artery catheter (Baxter Healthcare Corporation, Edwards Critical-Care Division, Santa Anna, California, USA). Pulmonary and right atrial pressures were measured using a Gould 850 pressure transducer, coupled to pressure modules and a Gould ES 1000 multichannel recorder (Gould Electronics, Ballainvilliers, France). The transducer was referenced at the mid-chest level in patients in the supine position. During the procedure, heart rate was measured by continuous electrocardiogram monitoring. Systolic and diastolic pressures were measured using an external sphygmomanometer (Dinamap; Critikon Inc, Tampa, Florida, USA). Cardiac

Table 2 Renal $\mathrm{O}_{2}$ derived variables according to the severity of cirrhosis (Pugh's classification, grade $A, B$, or $C$ )

\begin{tabular}{|c|c|c|c|}
\hline & \multicolumn{3}{|l|}{ Grade } \\
\hline & $A$ & $B$ & $C$ \\
\hline Arterial $\mathrm{O}_{2}$ content $(\mathrm{ml} / \mathrm{dl})$ & $14.3(0.4)$ & $14.1(0.4)$ & $13.7(0.4)$ \\
\hline Renal vein $\mathrm{O}_{2}$ content $(\mathrm{ml} / \mathrm{dl})$ & $13.4(0.5)$ & $12.4(0.4)^{\star}$ & $11.8(0.4)^{\star}$ \\
\hline $\begin{array}{l}\text { Renal arteriovenous } \mathrm{O}_{2} \text { content difference } \\
(\mathrm{ml} / \mathrm{dl})\end{array}$ & $0.91(0.10)$ & $1.78(0.08)^{\star}$ & $1.89(0.09)^{\star}$ \\
\hline Renal $\mathrm{O}_{2}$ consumption $\left(\mathrm{ml} / \mathrm{min} / \mathrm{m}^{2}\right)$ & $8.9(1.6)$ & $15.5(1.3)^{\star}$ & $18.0(1.5)^{\star} \dagger$ \\
\hline
\end{tabular}

Results are expressed as mean (SEM).

*Significantly different from corresponding values in grade A patients.

†Significantly different from corresponding values in grade $\mathrm{B}$ patients. output was measured by the thermodilution method using a bedside Edwards 9520-A cardiac output computer. Cardiac index (litres/ $\mathrm{min} / \mathrm{m}^{2}$ ) was calculated by dividing cardiac output by the body surface area (BSA). Mean arterial pressure (MAP, $\mathrm{mm} \mathrm{Hg}$ ) was calculated as follows: $\mathrm{MAP}=$ (systolic pressure $+(2$ $\times$ diastolic pressure))/3. Systemic vascular resistance (SVR, dyn.s $/ \mathrm{cm}^{5}$ ) was calculated as follows: $S V R=($ MAP - mean right atrial pressure $) \times(80 /$ cardiac output $)$.

An intravenous catheter was introduced into an antecubital vein, and inulin and $p$-aminohippurate (PAH) were infused to determine the glomerular filtration rate and renal plasma flow respectively. ${ }^{13}$ Inulin and PAH were given at a primer bolus of 50 and 12 $\mathrm{mg} / \mathrm{kg}$ respectively. Then a continuous infusion of inulin (15-30 mg/min) and PAH (6-12 $\mathrm{mg} / \mathrm{min}$ ) was administered for one hour to achieve steady state plasma concentrations. After this delay, blood samples were simultaneously taken from a peripheral vein and the right renal vein every minute for four minutes to measure PAH concentrations. An $8 \mathrm{~F}$ catheter was used to take blood samples from the right renal vein which had been previously visualised by injecting contrast medium into the catheter. The left renal vein was not used because of the occasional presence of splenorenal shunts in this territory. One hour after the onset of inulin infusion, peripheral blood samples were taken. Inulin and $\mathrm{PAH}$ concentrations were assayed after protein precipitation by colorimetry or acid hydrolysis respectively. In this series of patients, peripheral plasma concentrations of PAH and inulin were at steady state when blood samples were obtained. The glomerular filtration rate $(\mathrm{ml} / \mathrm{min})$ was equal to inulin clearance - that is, the ratio of the quantity of inulin infused per minute to the inulin concentration in a peripheral vein. The $8 \mathrm{~F}$ catheter was also used to measure inferior vena caval pressure in relation to the right renal vein. $\mathrm{PAH}$ extraction (EPAH, \%) was calculated according to the formula: $\mathrm{EPAH}=$ (peripheral vein $\mathrm{PAH}$ concentration - right renal vein $\mathrm{PAH}$ concentration)/peripheral vein $\mathrm{PAH}$ concentration. PAH clearance $(\mathrm{CPAH}, \mathrm{ml} / \mathrm{min})$ was calculated according to the formula: $\mathrm{CPAH}=$ quantity of PAH infused per minute/peripheral vein PAH concentration. Renal plasma flow (RPF, $\mathrm{ml} / \mathrm{min}$ ) was calculated according to the formula: $\mathrm{RPF}=\mathrm{CPAH} / \mathrm{EPAH}$. Renal blood flow $(\mathrm{RBF}, \mathrm{ml} / \mathrm{min})$ was calculated according to the formula: $\mathrm{RBF}=\mathrm{RPF} /(1-$ packed cell volume). The filtration fraction $(\mathrm{FF}, \%)$ was calculated according to the formula: $\mathrm{FF}=$ inulin clearance/RPF. Renal perfusion pressure (RPP, $\mathrm{mm} \mathrm{Hg}$ ) was calculated according to the formula: $\mathrm{RPP}=\mathrm{MAP}$ - inferior vena caval pressure. Renal vascular resistance (RVR, dyn.s $/ \mathrm{cm}^{5}$ ) was calculated according to the formula: $\mathrm{RVR}=(\mathrm{RPP} \times 80) / \mathrm{RBF}$.

MEASUREMENT OF NEUROHUMORAL SUBSTANCES Blood was taken from the pulmonary artery to determine plasma concentrations of neurohumoral factors. Plasma noradrenaline concentrations were measured by high performance 
Table 3 Renal haemodynamics and urinary sodium excretion according to the severity of cirrhosis (Pugh's classification, grade $A, B$, or $C$ )

\begin{tabular}{llll}
\hline & \multicolumn{2}{l}{ Grade } & \\
\cline { 2 - 4 } & $A$ & $B$ & $C$ \\
\hline PAH clearance (ml/min) & $550(63)$ & $479(28)$ & $517(49)$ \\
PAH extraction (\%) & $78(3)$ & $81(2)$ & $79(2)$ \\
Renal blood flow (litres/min) & $1.12(0.12)$ & $0.91(0.05)$ & $0.95(0.06)$ \\
Glomerular filtration rate (ml/min) & $103(8)$ & $95(5)$ & $99(8)$ \\
Filtration fraction (\%) & $15(1)$ & $17(1)$ & $17(1)$ \\
Renal perfusion pressure (mm Hg) & $77(3)$ & $70(2)^{\star}$ & $64(2)^{\star} \dagger$ \\
Inferior vena caval pressure $(\mathrm{mm} \mathrm{Hg})$ & $8.6(1.0)$ & $10.7(1.0)$ & $11.4(1.1)$ \\
Renal vascular resistance $($ dyn.s/cm $)$ & $6171(873)$ & $7317(662)$ & $6180(418)$ \\
Urinary sodium excretion $(\mu \mathrm{mol} / \mathrm{min})$ & $38(10)$ & $24(7)^{\star}$ & $19(9)^{\star} \dagger$ \\
& & & $<4 \ddagger$ \\
\hline
\end{tabular}

Results are expressed as mean (SEM).

PAH, $p$-aminohippurate

* Significantly different from corresponding values in grade A patients.

† Significantly different from corresponding values in grade B patients.

$\ddagger$ Patients $(\mathrm{n}=13)$ in whom urinary sodium was not detectable (lower than $5 \mathrm{mmol} / \mathrm{l}$ ).

Table 4 Plasma concentrations of renin, aldosterone, noradrenaline, and atrial natriuretic peptide according to the severity of cirrhosis (Pugh's classification, grade $A, B$, or $C$ )

\begin{tabular}{lccc}
\hline & \multicolumn{3}{l}{ Grade } \\
\cline { 2 - 4 } & $A$ & $B$ & $C$ \\
\hline Renin $(\mathrm{pg} / \mathrm{ml})$ & $52(30)$ & $160(34)$ & $351(77)^{\star} \dagger$ \\
Aldosterone $(\mathrm{pg} / \mathrm{ml})$ & $229(91)$ & $539(71)$ & $846(117)^{\star} \dagger$ \\
Noradrenaline $(\mathrm{pg} / \mathrm{ml})$ & $429(134)$ & $547(70)^{\star}$ & $1409(210)^{\star} \dagger$ \\
Atrial natriuretic peptide $(\mathrm{pg} / \mathrm{ml})$ & $63(12)$ & $155(30)$ & $89(20)$ \\
\hline
\end{tabular}

Results are expressed as mean (SEM).

${ }^{\star}$ Significantly different from corresponding values in grade A patients.

†Significantly different from corresponding values in grade B patients.

liquid chromatography with electrochemical detection. ${ }^{14}$ Plasma renin and aldosterone concentrations were measured by radioimmunoassay (Diagnostic Pasteur, Paris, France and Laboratoire Sorin, Antony, France respectively). ${ }^{8-11}$ Plasma atrial natriuretic peptide (ANP) concentrations were determined using a radioimmunoassay kit (Amersham, Les Ulis, France). ${ }^{9}$

MEASUREMENT OF $\mathrm{O}_{2}$ DERIVED VARIABLES

Blood samples were taken from the radial artery and the right renal vein for immediate measurement of $\mathrm{O}_{2}$ tension $\left(\mathrm{Po}_{2}, \mathrm{~mm} \mathrm{Hg}\right)$, haemoglobin concentrations $(\mathrm{Hb}, \mathrm{g} / \mathrm{dl})$ and oxyhaemoglobin saturation $\left(\mathrm{So}_{2}, \%\right) .{ }^{12}$ Oxygen tensions were measured at $37^{\circ} \mathrm{C}$ with specific electrodes whereas $\mathrm{Hb}$ and $\mathrm{So}_{2}$ were measured using the spectrophotometric method (2500 CO-Oxymeter; Corning Medical, Medfield, Massachusetts, USA). $\mathrm{O}_{2}$ contents $(\mathrm{ml} / \mathrm{dl})$ were calculated as follows: $\mathrm{O}_{2}$ content $=((\mathrm{Hb} \times 1.34$ $\left.\left.\times \mathrm{SO}_{2}\right)+\left(0.003 \times \mathrm{PO}_{2}\right)\right)$. Renal arteriovenous $\mathrm{O}_{2}$

Table 5 Systemic and splanchnic haemodynamics according to severity of cirrhosis (Pugh's classification, grade $A, B$, or $C$ )

\begin{tabular}{llll}
\hline & \multicolumn{2}{l}{ Grade } & \\
\cline { 2 - 4 } & $A$ & $B$ & $C$ \\
\hline Heart rate (beats/min) & $73(4)$ & $81(2)$ & $82(3)$ \\
Mean arterial pressure (mm Hg) & $85(2)$ & $80(2)$ & $75(2)^{\star}$ \\
Cardiac index (litres/min $\left./ \mathrm{m}^{2}\right)$ & $3.56(0.08)$ & $4.21(0.16)^{\star}$ & $4.60(0.18)^{\star}$ \\
Systemic vascular resistance $\left(\mathrm{dyn} . \mathrm{s} / \mathrm{cm}^{5}\right)$ & $964(48)$ & $878(36)^{\star}$ & $759(35)^{\star}$ \\
Right atrial pressure (mm Hg) & $4.7(0.7)$ & $4.5(0.5)$ & $4.3(0.5)$ \\
Pulmonary arterial pressure (mm Hg) & $12.9(1.1)$ & $14.7(0.7)$ & $14.2(0.7)$ \\
Pulmonary wedged pressure (mm Hg) & $8.0(1.0)$ & $8.1(0.6)$ & $8.3(0.6)$ \\
Wedged hepatic venous pressure $(\mathrm{mm} \mathrm{Hg})$ & $22.2(1.6)$ & $26.7(1.0)$ & $29.5(1.3)^{\star} \dagger$ \\
Free hepatic venous pressure (mm Hg) & $7.9(1.0)$ & $8.6(0.7)$ & $8.7(0.9)$ \\
Hepatic venous pressure gradient (mm Hg) & $14.3(1.2)$ & $18.1(0.7)^{\star}$ & $20.8(0.9)^{\star} \dagger$ \\
\hline
\end{tabular}

Results are expressed as mean (SEM).

*Significantly different from corresponding values in grade A patients.

†Significantly different from corresponding values in grade B patients. content difference $(\mathrm{ml} / \mathrm{dl})$ was calculated as arterial $\mathrm{O}_{2}$ content - renal vein $\mathrm{O}_{2}$ content. Renal $\mathrm{O}_{2}$ consumption $\left(\mathrm{ml} / \mathrm{min} / \mathrm{m}^{2}\right)$ was calculated from renal arteriovenous $\mathrm{O}_{2}$ content difference $\times \mathrm{RBF} \times \mathrm{BSA} \times 10$. Systemic arteriovenous $\mathrm{O}_{2}$ content difference $(\mathrm{ml} / \mathrm{dl}$ ) was calculated from arterial $\mathrm{O}_{2}$ content mixed venous $\mathrm{O}_{2}$ content. Systemic $\mathrm{O}_{2}$ consumption $\left(\mathrm{ml} / \mathrm{min} / \mathrm{m}^{2}\right)$ was calculated from systemic arteriovenous $\mathrm{O}_{2}$ content difference $\times$ $\mathrm{RBF} \times \mathrm{BSA} \times 10$.

OTHER MEASUREMENTS

The packed cell volume was measured by the microcrit method. Urinary sodium concentrations were measured using a specific electrode; concentrations lower than $5 \mathrm{mmol} / \mathrm{l}$ could not be measured in our laboratory.

STATISTICAL ANALYSIS

All results are expressed as means (SEM). One way analysis of variance was used to compare the variables in the different categories of Pugh's classification. Regression analysis was performed according to standard procedures. Significance was set at $\mathrm{p}<0.05$.

\section{Results}

Renal $\mathrm{O}_{2}$ consumption significantly increased with the severity of cirrhosis (table 2). Renal blood flow, glomerular filtration rate, and the filtration fraction did not differ significantly in patients with grade $\mathrm{A}, \mathrm{B}$, and $\mathrm{C}$ disease (table 3). Renal perfusion pressure was significantly lower in patients with grade $\mathrm{C}$ cirrhosis than in those with grade A or B. Renal sodium excretion significantly decreased as liver function declined (table 3). Urinary sodium concentration was lower than $5 \mathrm{mmol} / \mathrm{l}$ in 13 grade $\mathrm{C}$ patients, and therefore renal sodium excretion could not be calculated (table 3 ). In patients for whom sodium excretion could be calculated, there was a significant negative correlation between renal $\mathrm{O}_{2}$ consumption and sodium excretion $(r=0.40, \mathrm{p}<0.05)$.

Plasma concentrations of renin, aldosterone, and noradrenaline were available in 50,48 , and 55 patients respectively. They were higher in patients with grade $\mathrm{C}$ disease than in those with grade A (table 4). Plasma levels of both noradrenaline and aldosterone correlated independently with renal $\mathrm{O}_{2}$ consumption $(r=0.54$ and 0.44 respectively; $\mathrm{p}<0.05$ for both). Patients with grade $\mathrm{C}$ disease had a significantly higher cardiac index and lower mean arterial pressure and systemic vascular resistance than those with grade $\mathrm{A}$ (table 5). Wedged hepatic venous pressure and hepatic venous pressure gradient were significantly higher in patients with grade $\mathrm{C}$ disease than in those with grade $\mathrm{A}$. Systemic $\mathrm{O}_{2}$ consumption was significantly lower in grade $\mathrm{C}$ than in grade $\mathrm{A}$ or grade B (115 (5) $v 135$ (6) and 125 (5) $\mathrm{ml} / \mathrm{min} / \mathrm{m}^{2}$ respectively). No significant correlations were found between mean arterial pressure, wedged hepatic venous pressure, and hepatic venous pressure on the one hand and renal $\mathrm{O}_{2}$ consumption on the other $(r=0.08$, 0.07 , and 0.03 respectively; $\mathrm{p} \geqslant 0.6$ for all). 


\section{Discussion}

In this study, renal $\mathrm{O}_{2}$ consumption was significantly higher in patients with Pugh's grade $\mathrm{C}$ liver disease than in those with grade A. This finding indicates that the worsening of cirrhosis is associated with increased renal $\mathrm{O}_{2}$ demand. It has been suggested that increased renal $\mathrm{O}_{2}$ demand may play a role in the development of hepatorenal syndrome ${ }^{15}$ or result in a predisposition to ischaemic acute renal failure in cases of circulatory shock complicating severe cirrhosis. ${ }^{16}$

As expected, ${ }^{1-5}$ 8-11 17-22 plasma concentrations of neurohumoral substances (noradrenaline, renin, and aldosterone) were markedly increased in patients with severe cirrhosis. Noradrenaline, angiotensin II (a product of renin action), and aldosterone are known to stimulate the activity of sodium/potassium adenosine triphosphatase $\left(\mathrm{Na}^{+} / \mathrm{K}^{+}\right.$ATPase $)$in renal tubular cells. ${ }^{5}{ }^{6}$ As $\mathrm{Na}^{+} / \mathrm{K}^{+}$ATPase activity is an energy consuming process, ${ }^{6}$ the increase in $\mathrm{Na}^{+} / \mathrm{K}^{+}$ATPase activity induced by the above mentioned neurohumoral substances may explain, at least in part, increased renal $\mathrm{O}_{2}$ consumption in patients with grade $\mathrm{C}$ disease. This is supported by the significant correlation between renal $\mathrm{O}_{2}$ consumption and plasma levels of noradrenaline and aldosterone in this study. Stimulation of $\mathrm{Na}^{+} / \mathrm{K}^{+}$ATPase activity is the mechanism by which noradrenaline, angiotensin, and aldosterone increase renal tubular sodium reabsorption. ${ }^{523}$ [24[25] Therefore increased renal $\mathrm{O}_{2}$ consumption in grade $\mathrm{C}$ cirrhosis probably indicates enhanced renal tubular sodium reabsorption. This is supported by the significant inverse correlation between renal $\mathrm{O}_{2}$ consumption and sodium excretion in this study.

Plasma ANP concentrations did not differ significantly between patients with grade C disease and those with grade $\mathrm{A}$. This lack of increase in plasma ANP levels has already been reported in patients with severe cirrhosis. ${ }^{26}$ ANP is an important natriuretic hormone which decreases active sodium reabsorption (and thus $\mathrm{O}_{2}$ consumption) by inhibiting sodium pumps in renal tubular cells. ${ }^{27}$ Therefore the lack of increase in plasma ANP concentrations may contribute to increased renal $\mathrm{O}_{2}$ consumption and sodium retention in grade $\mathrm{C}$ cirrhosis.

This study confirms previous findings that systemic vasodilation increases as cirrhosis worsens. ${ }^{12}$ Systemic vasodilation stimulates noradrenaline and renin secretion. ${ }^{21}$ Therefore enhanced vasodilation may explain the increases in plasma concentrations of noradrenaline, renin, and aldosterone in patients with grade $\mathrm{C}$ disease. On the other hand, a worsening of liver disease is known to accentuate sinusoidal hypertension in patients with cirrhosis. ${ }^{12}$ It has been suggested that an increase in sinusoidal pressure activates the hepatorenal reflex, thus increasing efferent renal sympathetic nervous activity. ${ }^{28}$ The subsequent release of noradrenaline may stimulate sodium tubular reabsorption..$^{28}$ In this study, portal hypertension increased as cirrhosis worsened. Therefore we cannot exclude the possible contribution of increased sinusoidal hypertension to the activation of antinatriuretic neurohumoral substances in patients with grade $\mathrm{C}$.

As expected, ${ }^{12}$ systemic $\mathrm{O}_{2}$ consumption was significantly lower in patients with grade $\mathrm{C}$ disease than in those with grade $\mathrm{A}$. This result contrasts with the above finding that renal $\mathrm{O}_{2}$ consumption was significantly higher in grade $\mathrm{C}$ than in grade $\mathrm{A}$ disease. Thus, the worsening of cirrhosis is associated with an alteration in $\mathrm{O}_{2}$ consumption which differs between systemic and renal territories.

The lack of difference in the glomerular filtration rate between patients with grade $\mathrm{C}$ and grade $\mathrm{A}$ disease indicates that a decrease in glomerular filtration rate (via the subsequent decline in sodium filtered load) does not contribute to the cirrhosis associated sodium retention found in this study. A lack of decrease in glomerular filtration rate has already been shown in patients with severe cirrhosis. ${ }^{13}$

In conclusion, this study shows for the first time that, in patients with cirrhosis, worsening of the disease is associated with an increase in renal $\mathrm{O}_{2}$ consumption. The results suggest that increased renal $\mathrm{O}_{2}$ consumption is due to renal tubular sodium retention caused by increased neurohumoral antinatriuretic substances. This neurohumoral activation is related to cirrhosis induced vasodilation.

The authors thank Christiane Bertin and Christine Dauvergne for their technical assistance.

1 Arroyo V, Ginès P. Mechanism of sodium retention and ascites formation in cirrhosis. F Hepatol 1993;17(suppl 2):S24-8

2 Wong F, Blendis L. Pathophysiology of sodium retention and ascites formation in cirrhosis: role of atrial natriuretic factor. Semin Liver Dis 1994;14:59-70.

3 Gentillini P, La Villa G, Romanelli RG, et al. Pathogenesis and treatment of ascites in hepatic cirrhosis. Cardiology 1994;84(suppl 2):68-79.

4 Wood LJ, Massie D, McLean AJ, et al. Renal sodium retention in cirrhosis: tubular site and relation to hepatic dysfunction. Hepatology 1988;8:831-6.

5 Moreau R, Lebrec D. Transduction of antinatriuretic signals in renal proximal tubular cells in cirrhosis. Introduction to novel approaches to the treatment of sodium retention. $\mathcal{f}$ novel approaches to the

6 Silva P. Renal fuel utilization, energy requirements, and function. Kidney Int 1987;32(suppl 22):9-14.

7 Pugh RNH, Murray-Lyon IM, Dawson JL, et al. Transection of the oesophagus for bleeding oesophagus varices. $\mathrm{Br}$ f Surg 1973;60:646-9.

8 Roulot D, Moreau R, Gaudin C, et al. Long-term sympathetic and hemodynamic responses to clonidine in patients with cirrhosis and ascites. Gastroenterology 1992; 102:1309-18.

9 Brenard R, Moreau R, Pussard E, et al. Hemodynamic and sympathetic responses to human atrial natriuretic peptide infusion in cirrhotic patients. F Hepatol 1992;14:347-56.

10 Lebrec D, Giuily N, Hadengue A, et al. Transjugular intrahepatic portosystemic shunts: comparison with paracentesis in patients with cirrhosis and refractory ascites: a randomized trial. F Hepatol 1996;25:135-44.

11 Gadano A, Moreau R, Vachiery F, et al. Natriuretic response to the combination of atrial natriuretic peptide and terlipressin in patients with cirrhosis and refractory ascites. f Hepatol 1997; 26:1229-34.

2 Moreau R, Lee SS, Soupison T, et al. Abnormal tissue oxygenation in patients with cirrhosis and liver failure. $\mathcal{F}$ Hepatol 1988;7:98-105.

13 Moreau R, Gaudin C, Hadengue A, et al. Renal hemodynamics in patients with cirrhosis: relationship with ascites and liver failure. Nephron 1993;65:359-63.

14 Hjemdahl P. Catecholamine measurements by highperformance liquid chromatography. Am F Physiol 1984; 247:E13-20.

15 Moore K. The hepatorenal syndrome. Clin Sci 1997;92: 433-43.

16 Thadhani R, Pascual M, Bonventre JV. Acute renal failure. $N$ Engl F Med 1996;334:1448-60. 
17 Arroyo V, Bosch J, Mauri M, et al. Renin aldosterone and renal hemodynamics in cirrhosis with ascites. Eur $\mathcal{F}$ Clin renal hemodynamic

18 Wilkinson SP, Smith IK, Williams R. Changes in plasma renin activity in cirrhosis: a reappraisal based on studies in 67 patients and "low-renin" cirrhosis. Hypertension 1979;1: 125-9.

19 Bichet DG, Van Putten VJ, Schrier RW. Potential role of increased sympathetic activity in impaired sodium and water excretion in cirrhosis. $N$ Engl f Med 1982;307:1552-7.

20 Bernardi M, Santini C, Trevisiani F, et al. Plasma norepinephrine, weak neurotransmitters, and renin activity during active tilting in liver cirrhosis: relationship with cardiovascular homeostasis and renal function. Hepatology 1983;3: 56-64.

21 Schrier RW, Arroyo V, Bernardi M, et al. Peripheral arterial vasodilation hypothesis: a proposal for the initiation of renal sodium and water retention in cirrhosis. Hepatology 1988;8:1151-7.
22 Bernardi M, Trevisani F, Gasbarrini A, et al. Hepatorenal disorders: role of the renin-angiotensin-aldosterone sysdisorders: role of the renin-angioten
tem. Semin Liver Dis 1994;14:23-34.

23 Garg LC. Actions of adrenergic and cholinergic drugs on renal tubular cells. Pharmacol Rev 1992;44:81-102.

24 Cogan MD. Angiotensin II: a powerful controller of sodium transport in the early proximal tubule. Hypertension 1990;15:451-8.

25 Crabbe J. Mechanism of action of aldosterone. In: deGroot LJ, ed. Endocrinology. Philadelphia: WB Saunders, 1989: 1572-81.

26 Gerbès AL. The role of atrial natriuretic peptide (ANP) in chronic liver disease. Pharmacol Ther 1993;58:381-90.

27 Aperia A, Holtbäck U, Syrén ML, et al. Activation/ deactivation of renal $\mathrm{Na}^{+}, \mathrm{K}^{+}$-ATPase: a final common pathway for regulation of natriuresis. FASEB $f$ 1994;8: 436-9.

28 DiBona GF. Renal neural activity in hepatorenal syndrome. Kidney Int 1984;25:841-53. 